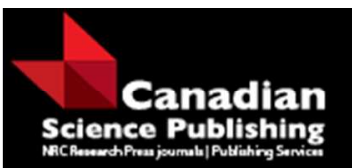

Canadian Journal of Forest Research Revue canadienne de recherche forestière

\title{
Optimization of Beauveria bassiana in a spray formulation against Choristoneura fumiferana.
}

\begin{tabular}{|r|l|}
\hline Journal: & Canadian Journal of Forest Research \\
\hline Manuscript ID & cjfr-2015-0435.R1 \\
\hline Manuscript Type: & Article \\
\hline Date Submitted by the Author: & 11 -Jan-2016 \\
\hline Complete List of Authors: & Hicks, Barry; College of the North Atlantic, \\
\hline Keyword: & $\begin{array}{l}\text { Eastern spruce budworm, entomopathogenic fungi, Beauveria bassiana, } \\
\text { formulation, Ultra low-volume spray }\end{array}$ \\
\hline \multicolumn{2}{|l}{} \\
\hline
\end{tabular}


1 Optimization of Beauveria bassiana in a spray formulation

2 against Choristoneura fumiferana.

4 Barry J. Hicks

5

6 College of the North Atlantic, 4 Pike's Lane, Carbonear, NL, A1Y 1A8.

11 Author for correspondence.

12

13 Barry J. Hicks, College of the North Atlantic, 4 Pike's Lane, Carbonear, NL, A1Y 1A8.

14 Telephone (709) 596-8956; facsimile (709) 596-2688; e-mail barry.hicks@cna.nl.ca 15 


\section{Optimization of Beauveria bassiana in a spray formulation}

\section{7 against Choristoneura fumiferana.}

19 Barry J. Hicks, College of the North Atlantic, 4 Pike's Lane, Carbonear, NL, A1Y 1A8.

\section{Abstract}

22 Most mycoinsecticides require a carrier of natural or synthetic oils for them to be

23 effective when sprayed on forest defoliating caterpillars such as the eastern spruce

24 budworm (Choristoneura fumiferana). Two isolates of Beauveria bassiana conidia were

25 formulated in natural (vegetable) and synthetic (mineral) oils and tested against late instar

26 larvae of the budworm. Topical application showed that the ARSEF 1850 isolate to be

27 more effective than a commercially available strain. Additional laboratory spray trials

28 using a hand-held spinning disc sprayer showed that ARSEF 1850 natural oil formulation

29 significantly increased mortality when compared to controls. The use of oil formulated

30 B. bassiana conidia should be considered for future budworm management under the

31 integrated pest management of this pest in North America.

33 Keywords

34 Eastern spruce budworm, entomopathogenic fungi, Beauveria bassiana, formulation 


\section{L'optimisation de la formulation de Beauveria bassiana dans}

39 une pulverisation contre - Choristoneura fumiferana.

\section{Résumé}

La plupart des mycoinsecticides exigent l'emploi d'huiles naturelles ou synthétiques afin d'en assurer l'efficacité lorsqu'ils sont pulvérisés sur les lépidoptères forestiers défoliateurs comme la tordeuse des bourgeons de l'épinette (Choristoneura fumiferana). Deux isolats des conidies Beauveria bassiana ont été formulées dans les huiles naturelles (végétales) et synthétiques (minéraux) et sont testés contre des larves de dernier stade des tordeuses des bourgeons de l'épinette. Des applications topiques ont montré que la isolats ARSEF 1850 est plus efficace disponible commercialement. Les essais supplémentaires de laboratoire, en utilisant un pulvérisateur manuel à disques rotatifs, ont montré que la formulation d'huile naturelle (ARSEF 1850) a considérablement augmenté la mortalité lorsqu'on les compare à des témoins. L'utilisation d'une conidie B. bassiana à base d'huile devrait être considérée pour la gestion de l'avenir de la tordeuse des bourgeons de l'épinette sous la gestion intégrée des organismes nuisibles comme ce ravageur en Amérique du Nord. 


\section{Introduction}

42 There are several lepidopteran species that are considered pests of trees in the Boreal

43 Forest. Of them, the eastern spruce budworm, Choristoneura fumiferana (Clemens) is

44 most notable. This species is a serious pest of conifers of North America and has a long

45 history of outbreaks dating back several hundred years (Blais 1983; Morin et al. 1993;

46 Krause 1997; Boulanger and Arsenault 2004)

48 The management of forest insect pest populations is achieved mainly by the use of all

49 available strategies. Targeted insecticide use is a strategy that is used under the

50 Integrated Pest Management (IPM) approach, however all attempts are made to limit

51 their harm to other components of the ecosystem. During the past two decades there has

52 been a concerted effort to reduce the reliance on broad-spectrum chemical insecticides in

53 forestry and to employ other environmentally acceptable strategies. The main microbial

54 agent that is used today against forest pest Lepidoptera is the bacterium Bacillus

55 thuringiensis $(\mathrm{Bt})$ which is relied upon heavily in many jurisdictions. It is within the IPM

56 ideology that the importance of seeking alternative strategies becomes apparent. The

57 entomopathogenic fungus, Beauveria bassiana (Balsama) Vuillemin (Ascomycota:

58 Hypocreales) has been known for 170 years (Zimmerman 2007). It is a naturally

59 occurring soil-dwelling fungus that grows as a saprophyte (Bidochka et al.1998) but it is

60 also a highly effective entomopathogenic fungus that causes diseases in a variety of

61 insect species, mostly in the orders: Lepidoptera, Coleoptera and Homoptera. In fact, $B$.

62 bassiana has been one of the most studied entomopathogenic fungi and a considerable

63 volume of literature has accumulated on its biology, hosts, effects on non-target 
64 organisms, and safety towards vertebrates (e.g., Ferron 1985; Goettal et al. 1990; Saik et

65 al. 1990; Semalulu et al. 1992; Feng et al. 1994; Vestergaard et al. 2003; Zimmerman 66 2007).

68 Shortly after the turn of the 20th century, fungal species were field-tested against

69 different forestry pests. Because the fungi have strict environmental requirements for

70 germination that were not met at the time, the applications failed to produce significant

71 mortality. Entomopathogenic fungi were labeled as ineffective and scientists in the

72 western countries lost interest in these organisms (Ferron 1985). The use of fungi $(B$.

73 bassiana in particular) has not been exploited as potential controlling agents against

74 serious forest Lepidoptera in North America and Europe. The commercial use of $B$.

75 bassiana in North America has been limited mainly to greenhouses and agricultural plots.

76 This use in North America contrasts significantly with China, where B. bassiana was

77 successfully applied on pine feeding Lepidoptera over a 36-year period (Feng et al. 1994;

78 Li 2007; Wang and Feng 2014). The limiting environmental factor for fungal spore

79 germination is their requirement for high humidity. Advances in the formulation of the

80 fungal spores in natural and synthetic oils have practically eliminated the problem of the

81 high humidity requirement (Bateman et al. 1993).

82

83 Initial research by Hicks (2007) involved the selection of Lepidoptera specific $B$.

84 bassiana isolates. The research showed that an isolate originally taken from a

85 Choristoneura sp. caterpillar was very effective in lab bioassays against this insect.

86 Furthermore, it was shown that this fungus had good potential for further development 
87 because of good long-term storage and its low impact on non-target organisms (Hicks

88 2007; Hicks et al. 2011).

90 The purpose of this research is to optimize a formulation of B. bassiana that could

91 effectively be sprayed against forest caterpillars (namely the spruce budworm).

\section{Methods and Materials}

94 Fungus. A fungal isolate (ARSEF 1850 - Dr. R Humber, USDA Plant Protection

95 Research Unit, Ithica, NY) that was identified earlier by Hicks et al. (2011) as effective

96 against C. fumiferana, was grown on Sabouraud maltose + yeast extract agar in $9 \mathrm{~cm}$ Petri

97 dishes. Spores were harvested by suction using a Mycoharvester Mk 5 (VBS Agriculture

98 Ltd., Beaconsfield, UK). Botanigard $^{\circledR}$ (Koppert Canada Ltd, Scarborough, Ontario), a

99 commercial B. bassiana product, was also tested.

101 Spruce budworm. Spruce budworm $2^{\text {nd }}$ instar larvae, located within their overwintering

102 hibernacula, were supplied by Insect Production Services (Canadian Forest Service, Sault

103 Ste. Marie, Ont.). The larvae were reared in 30ml plastic cups with paper lid inserts on

104 an artificial diet (Insect Production Services, Canadian Forest Service, Sault Ste. Marie,

105 Ont.) in a ConViron ${ }^{\circledR}$ environmental growth chamber (Controlled Environments Ltd.,

106 Winnipeg, Manitoba) at $23^{\circ} \mathrm{C}, 75 \%$ relative humidity, and 18L:6D photoperiod.

107

108 Sprayer. A Micron "ulva+" hand-held spinning disc sprayer (Dramm Corporation 109 Canada, Fenwick, Ontario) was used during the spray trials. 
111 Formulation. Bateman et al. (2007) outlined some of the procedures for formulating 112 fungal spores for spraying. The spores were delivered to the spray-head in a formulation

113 consisting of oil that was either a general vegetable cooking oil containing canola and/or

114 soybean oil (Sardo Foods, Bolton, Ont.) or a mineral oil (Fischer Scientific). In both

115 cases, kerosene (Canadian Tire Corp.) was used as the solvent. Different mixtures were

116 passed through a standard B2 viscosity cup (ElectroPhysik USA, Inc, Arlington Heights,

117 Illinois, USA.) to determine their viscosities. The correct viscosity for spraying through a

118 Micron "Ulva+" sprayer is one that will flow through the viscosity cup in 45 seconds.

120 Topical applications of formulations containing Botanigard ${ }^{\circledR} . \quad 30$ grams of

121 Botanigard $^{\circledR}$ was suspended in $300 \mathrm{ml}$ of the formulation to be tested. The initial tests

122 determined the efficacy of the product with topical application only. In this case, four $\mu 1$

123 of the formulation was applied directly to the mid-dorsal surface of $6^{\text {th }}$ instar larvae using

124 a micropipette. Ten larvae composed a replicate and three replicates were treated.

125 Controls consisted of three replicates of sterile water treated larvae and three replicates of

126 the tested carrier mixture without the fungal spores. The larvae were rear individually in

$12730 \mathrm{ml}$ cups supplied with ample diet. The larvae were reared in the growth chamber under

128 conditions stated above and monitored daily for mortality or signs of fungal disease until

129 pupation. Dead larvae were placed in saturated environments to see of sporulating fungi

130 would become evident.

132 Spray trials of formulations containing Botanigard ${ }^{\circledR}$ and ARSEF 1850. Calibration 
133 of the spraying trials was accomplished using the procedures of Bateman et al. (2007).

134 Field studies that employ ultra-low volume (ULV) application rates of two litres per

135 hectare are common for mycoinsecticide spraying. Experimentation showed that, in the

136 lab, such a rate would be accomplished if the sprayer was held (one metre high) over the 137 insects for a three second time period. Spore formulations were made using both

138 Botanigard $^{\circledR}$ and ARSEF 1850. For each strain, $0.5 \mathrm{~g}$ of spores was suspended in $100 \mathrm{ml}$

139 of the 50:50 (vegetable oil to kerosene) carrier. The sprayer was fitted with the red 140 restrictor that limited the flow rate to $74.4 \mathrm{ml} / \mathrm{min}$. An improved Neubauer 141 haemocytometer was used to count the number of spores for the ARSEF formulation. It 142 was determined to have $3.35 \times 10^{6}$ spores $/ \mathrm{ml}$. According to the number of spores per gram 143 indicated on the Botanigard ${ }^{\circledR}$ label, the formulation had $2.2 \times 10^{8}$ spores $/ \mathrm{ml}$. For spraying, 144 ten larvae (comprising one replicate) were placed onto a $1 \mathrm{~m}^{2}$ metal pan lined with paper 145 toweling with the sprayer held over the pan for three seconds. Four replicates were 146 treated. An additional four replicates were left untreated; four with distilled water and 147 four with the 50:50 (vegetable oil to kerosene) carrier as controls. We conducted a 148 second experiment involving fungal spores suspended in the carrier where four replicates 149 of larvae were sprayed for six seconds. Larvae were placed individually in their own

$15030 \mathrm{ml}$ cup containing diet and reared under the same environmental conditions as the main 151 culture (see above). Larvae were monitored daily for mortality until pupation. Any cups 152 with dried diet were replaced with a cup containing fresh diet.

154 Spray trials using Botanigard ${ }^{\circledR}$ and ARSEF 1850 with spray droplet size and density 155 measurements to more accurately determine amounts applied. To determine the 
156 amount of fungal spores reaching the larvae, we measured the mean droplet density and

157 mean droplet volume. Mean density (drops per $\mathrm{mm}^{2}$ ) was measured by spraying the 158 formulation onto five clean standard microscope slides (at $1 \mathrm{~m}$ high for 3 seconds) and 159 then counting the total drops within five random $1 \mathrm{~mm}^{2}$ squares on each slide ( 25 total 160 counted) under microscopy. To determine the mean volume, we sprayed the formulation 161 onto spruce budworm larva silk that was suspended across the well of a depression slide.

162 Five slides were sprayed and 27 droplets that landed on the silk threads were chosen 163 randomly and measured. The diameters of the droplets were measured under a Leica 164 MZ6 stereomicroscope using LAS measuring software (Leica Microsystems Canada, 165 Toronto, Ont.)(Fig. 1). Mean volume of the droplets was calculated from the diameter 166 measurements (see Anonymous (online) for formula calculations).

168 For the Botanigard $^{\circledR}$ spray trials, 20g of Botanigard ${ }^{\circledR}$ spores were suspended in $200 \mathrm{ml}$ of 169 the 50:50 (vegetable oil to kerosene) carrier. It was determined that the smaller yellow 170 restrictor produced spray droplet diameters of the size required in ULV spraying. In this 171 case, the flow rate was reduced to $31.3 \mathrm{ml} / \mathrm{min}$. Ten larvae (comprising one replicate) 172 were placed onto a $1 \mathrm{~m}^{2}$ metal pan lined with paper toweling with the sprayer held over 173 the pan for three seconds. Five replicates were treated. An additional five replicates 174 were sprayed with distilled water and five with the 50:50 (vegetable oil to kerosene) 175 carrier as controls. We conducted a second experiment involving the Botanigard ${ }^{\circledR}$ spores 176 suspended in the carrier where five replicates of larvae were sprayed for five seconds. 177 Larvae were placed individually in $30 \mathrm{ml}$ cups containing diet and reared under the same 178 environmental conditions as the main culture (see above). Larvae were monitored daily 
179 for mortality until pupation.

180

181 For the ARSEF 1850 spray trials, 6.82g of ARSEF 1850 spores were suspended in $50 \mathrm{ml}$

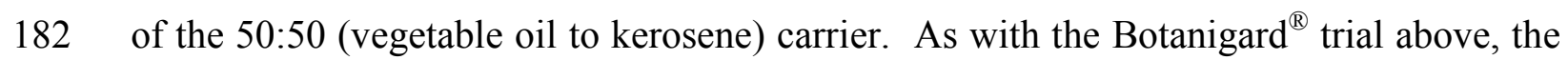

183 smaller yellow restrictor was used and the flow rate was $31.3 \mathrm{ml} / \mathrm{min}$. 10 larvae

184 (comprising one replicate) were placed onto a $1 \mathrm{~m}^{2}$ metal pan lined with paper toweling

185 with the sprayer held over the pan for three seconds. Four replicates were treated. An

186 additional four replicates were unsprayed and four with the 50:50 (vegetable oil to

187 kerosene) carrier as controls. Another four replicates were sprayed for six seconds.

188 Larvae were placed individually in $30 \mathrm{ml}$ cups containing diet and reared under the same

189 environmental conditions as the main culture (see above). Larvae were monitored daily

190 for mortality until pupation.

191

192 Statistical analysis. Where applicable, analysis of variance (ANOVA) was used to

193 determine the significance between treatments and controls (Minitab Version 14).

195 Results and Discussion

196 Carrier mixture selection. Upon experimentation with the viscosity cup it was

197 determined that two mixtures of oil and kerosene would adequately flow through the cup

198 in the required 45 second time frame. Form-1 had a 70:30 mixture of mineral oil and

199 kerosene while form-2 had 50:50 of vegetable oil and kerosene.

201 Topical application onto $6^{\text {th }}$ instar spruce budworm larva. The total number of 
202 Botanigard $^{\circledR}$ fungal spores in the four $\mu$ applied to each larva was $9.0 \times 10^{6}$ spores. That 203 amount of spores topically applied to budworm larvae was detrimental to the budworm as 204 no larvae survived no matter what oil carrier was used (Table 1). The 70:30 (mineral oil 205 to kerosene) carrier alone negatively impacted the larvae with only $13.3 \%$ surviving to 206 pupation. That is considerably lower than the water treated controls ( $90 \%$ surviving). The $20750: 50$ (vegetable oil to kerosene) carrier had 46.7\% surviving. It was concluded that the $20850: 50$ (vegetable oil to kerosene) carrier would be best to explore further. An additional 209 conclusion here was that Botanigard $^{\circledR}$ appeared to be effective in killing spruce budworm 210 larvae.

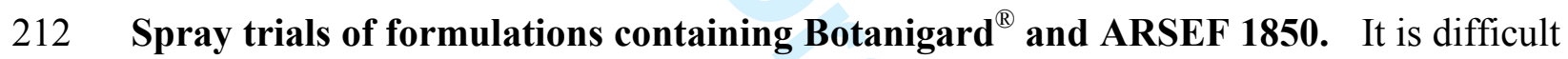

213 to determine how many spores actually land on the caterpillars when spraying with a

214 suspension. The red restrictor on the spray-head limited the flow rate to $74.4 \mathrm{ml} / \mathrm{min}$.

215 For the ARSEF formulation, $3.3 \times 10^{5}$ spores $/ \mathrm{ml}$ were counted using the improved 216 Neubauer haemocytometer. Therefore $1.2 \times 10^{6}$ spores were released from the spray-head

217 over the 3 seconds that the sprayer was held in place. If we assume that the plume of the 218 spray covered $3 \mathrm{~m}^{2}$ and that the mean surface area of a $6^{\text {th }}$ instar larvae is about $21970.69 \mathrm{~mm}^{2}$, then it is estimated that approximately 40 spores may have landed on each 220 larva. This amount is very low compared to Hicks (2007) who showed the $\mathrm{LD}_{50}$ for this 221 fungal strain on $6^{\text {th }}$ instar larvae was 27,000 spores per larva. The data for the present 222 study showed $82.5 \%$ survival of larvae sprayed for 3 seconds (Table 2). When we 223 sprayed the larvae for double time (6 seconds $=80$ spores/larva) the percent surviving 224 decreased to $60 \%$. This was significantly lower than the untreated and water treated 
225 controls, but failed (marginally) to reach statistical significance with the formulation

226 control $(\mathrm{P}=0.058)$.

228 For the Botanigard ${ }^{\circledR}$ spray, the red restrictor allowed $8.18 \times 10^{8}$ spores to be released from

229 the spray-head. Again, if we assume that the plume covered three $\mathrm{m}^{2}$ and that the surface

230 area of a typical $6^{\text {th }}$ instar larva is $70.69 \mathrm{~mm}^{2}$, then 27,648 spores may have landed on

231 each sprayed larva. While this is comparable to the $\mathrm{LD}_{50}$ indicated by Hicks (2007) it

232 must be noted that this is a different strain and is thought not to be as effective as one

233 isolated from a spruce budworm (Hicks 2007). The present data suggests that the

234 ARSEF strain is more effective because, while there were a significantly smaller number

235 of ARSEF spores sprayed onto larvae, the percent surviving was the same as

236 Botanigard $^{\circledR}$.

238 Spray trials using Botanigard ${ }^{\circledR}$ and ARSEF 1850 with spray droplet size and density

239 measurements to more accurately determine amounts applied. For this trial, the

240 yellow restrictor was used on the spray head and this reduced the flow rate to 31.3

$241 \mathrm{ml} / \mathrm{min}$. At this flow rate, $1.57 \mathrm{ml}$ was sprayed during the three seconds that the sprayer

242 was held into position. The measurement of mean droplet density showed 1.84

243 drops $/ \mathrm{mm}^{2}$. The mean droplet diameter was used to calculate mean droplet volume of

$2447.54 \times 10^{-6} \mathrm{ml}$. The surface area of a generalized $6^{\text {th }}$ instar budworm larva is about

$24570.69 \mathrm{~mm}^{2}$. Each larva thus received about 130.1 droplets $\left(70.69 \mathrm{~mm}^{2} \mathrm{x} 1.84\right.$

246 droplets $\left./ \mathrm{mm}^{2}\right)$. The volume applied to a budworm larva was $1.95 \times 10^{-3} \mathrm{ml} /$ larva $(130.1$

247 droplets $\times 7.54 \times 10^{-6} \mathrm{ml}$ ). With $20 \mathrm{~g}$ of Botanigard ${ }^{\circledR}$ spores mixed in $200 \mathrm{ml}$ of carrier, 
248 there was $4.4 \times 10^{9}$ spores $/ \mathrm{ml}$ (determined by the information indicated on the Botanigard ${ }^{\circledR}$

249 label). The number of Botanigard ${ }^{\circledR}$ spores sprayed on a larva over three seconds was

$2508.58 \times 10^{6}$ spores/larva. For a five second spray, there were $1.43 \times 10^{7}$ spores sprayed on

251 each larva. The application of Botanigard ${ }^{\circledR}$ spores to spruce budworm larvae showed a

252 typical dose-response (Table 3 ). As the amount of Botanigard ${ }^{\circledR}$ applied increased, the

253 percent of surviving larvae was significantly reduced. The amounts of Botanigard ${ }^{\circledR}$

254 sprayed that caused mortality was considerably higher than the amount of the B. bassiana

255 strains used by Hicks (2007). This is not surprising as the strain of B. bassiana occuring

256 in Botanigard $^{\circledR}$ was initially isolated from a grasshopper (Orthoptera) and would likely

257 not be as effective across different insect orders. Xu (1988) indicated that isolates of $B$.

258 bassiana tend to have higher virulence to their original hosts, or species closely related to

259 the original hosts. Alternatively, we cannot rule out the possibility that the Botanigard ${ }^{\circledR}$

260 was negatively affected by the oil carrier.

262 For the ARSEF 1850 trials, the mean droplet volume was $7.54 \times 10^{-6} \mathrm{ml}$, each larva

263 received 130.1 droplets and the volume applied was $1.95 \times 10^{-3} \mathrm{ml} / \mathrm{larva}$. With $6.82 \mathrm{~g}$ of

264 ARSEF 1850 spores suspended in 50ml of the 50:50 (vegetable oil to kerosene) carrier,

265 there were $1.4 \times 10^{6}$ spores $/ \mathrm{ml}$ (determined using an improved Neubauer

266 haemocytometer). The number of spores sprayed on each larva for 3 seconds was 8190

267 spores/larva while 16380 spores/larva were sprayed onto each larva over six seconds.

268 Table 4 shows that spraying with ARSEF 1850 was very effective against $6^{\text {th }}$ instar larvae

269 of the spruce budworm. The application of 8190 spores/larva caused $42.5 \%$ surviving

270 larvae while 16380 spores/larva resulted in only 15\% surviving. Hicks (2007) showed 
271 the $\mathrm{LD}_{50}$ for this fungal isolate suspended in water and topically applied to $6^{\text {th }}$ instar

272 larvae was 27,000 spores per larva. The present data indicates that formulating the spores

273 in 50:50 (vegetable oil to kerosene) increased the virulence of this strain. Prior et al.

274 (1988) showed that oil formulations of B. bassiana were 30 times more effective at 275 controlling Pantorhytes plutus (Coleoptera: Curculionidae) than water formulated 276 conidia. Similarly, Moslin et al. (2004) showed increased infectivity of B. bassiana 277 toward larvae of the oil palm bagworm, Metisa plana (Lepidoptera: Pscyhidae) when 278 formulated in either natural (Soybean) of synthetic $($ Parafin $=$ mineral) oils. Ummidi and

279 Vadlamani (2014) bioassayed B. bassiana conidia formulated in several natural oils 280 against Spodoptera litura (Lepidoptera: Noctuidae) and showed that all formulations

281 displayed higher mortalities in the targeted pest than compared to unformulated conidia.

282 Kirubakaran et al. (2014) showed that canola oil-formulated B. bassiana condia was more

283 virulent to all stages of the rice leafroller, Cnaphalocrocis medinalis (Lepidoptera:

284 Pryralidae). Finally, similar results have been shown for Metarhizium flavoviride 285 (Bateman et al. 1993; Ummidi and Vadlamani 2014; Kirubakaran et al. 2014), Nomuraea 286 rileyi, and Isaria tenuipes (Vega-Aquino et al. 2010).

\section{Conclusions}

289 Entomopathogenic fungi are affected by many environmental factors, including low 290 humidity, UV radiation, and temperatures. In the past, failure of entomopathogens in 291 field experiments occurred because these limiting factors were not taken into 292 consideration with the consequence of labelling entomopathogens ineffective for use in 293 forestry. This is not the case now as several studies have shown that formulating fungal 
294 spores in natural and synthetic oils minimize the limiting factors and have opened the

295 doors to their use in forest ecosystems under an IPM approach. Delgado et al. (1999)

296 showed that B. bassiana conidia formulated in synthetic oil combined with

297 concentrations of Dimilin ${ }^{\circledR}$ (Diflubenzuron) had synergistic effects on grasshoppers in the

298 Sahel of Africa. If B. bassiana can be formulated to be effective under low humidity

299 conditions of the Sahel, then its use in the Boreal Forest is achievable. The present study

300 has shown that formulation of Beauveria bassiana conidia in a natural oil (i.e. vegetable

301 oil) carrier is effective in controlling spruce budworm larvae when sprayed with ultra-low

302 volume regimes. While some caution should be exercised when interpreting the values

303 calculated as several assumptions were made that may have affected the true values, the

304 general results showed that this fungus has considerable promise in IPM of the Eastern

305 Spruce Budworm. Future trials should involve more complex greenhouse and/or field 306 experiments.

307

308 Acknowledgments

309 Funding was provided by Spray Efficacy Research Group partners (Department of

310 Natural Resources, Newfoundland and Labrador; and Department of Natural Resources,

311 Nova Scotia). Additional funding came from the Centre for Forest Science and

312 Innovation (Department of Natural Resources, Newfoundland and Labrador) and

313 considerable in-kind support from the College of the North Atlantic. K. Baker and R.

314 Sellars provided technical help. 


\section{References}

318 Bateman, R.P., Carey, M., Moore, D., and Prior, C. 1993. The enhanced infectivity of

319 Metarhizium flavoviride in oil formulations to desert locusts at low humidities. Ann 320 Appl. Biol. 122:145-152.

321

322 Bateman, R.P., Matthews, G.A., and Hall, F.R. 2007. Ground-based application 323 equipment. In Field Manual of Techniques in Invertebrate Pathology. Edited by L. Lacey 324 and H. Kaya. Springer, Netherlands, pp. 73-98.

326 Bidochka, M.J., Kasperski, J.E. and Wild, G.A.M. 1998. Occurrence of the

327 entomopathogenic fungi Metarhizium anisopliae and Beauveria bassiana in soils from 328 temperate and near-northern habitats. Can. J. Bot. 76:1198-1204.

330 Blais, J.R. 1983. Trends in the frequency, extent, and severity of spruce budworm 331 outbreaks in eastern Canada. Can. J. For. Res. 13:539-547.

333 Boulanger, Y. and Arseneault, D. 2004. Spruce budworm outbreaks in eastern Quebec 334 over the last 450 years. Can. J. For. Res. 34:1035-1043.

336 Delgado, F.X., Britton, J.H., Onsager, J.A. and Swearingen, W. 1999. Field assessment of 337 Beauveria bassiana (Balsamo) Vuillemin and potential synergism with Diflubenzuron for 338 control of Savanna grasshopper complex (Orthoptera) in Mali. J. Invertebr. Pathol. 
341 Feng, M.G., Poprawski, T.J. and Khachatourians, G.G. 1994. Production, formulation

342 and application of the entomopathogenic fungus Beauveria bassiana for insect control:

343 current status. Biocontrol Science and Technology 4:3-34.

345 Ferron, P. 1985. Fungal Control. In Comprehensive insect physiology, biochemistry and

346 pharmacology. Vol. 10. Edited by L.I. Gilbert and G.A. Kerkut. Pergamon Press,

347 London, pp. 313-346.

349 Goettel, M.S., Poprawski, T.J., Vandenberg, J.D., Li, Z. and Roberts, D.W. 1990. Safety

350 to nontarget invertebrates of fungal biocontrol agents. In, Safety of Microbial

351 Insecticides. Edited by M. Laird, L.A. Lacey, and E.W. Davidson. CRC Press, Boca

352 Raton, pp209-231.

354 Hicks, B.J. 2007. Laboratory development of the fungus Beauveria bassiana as a

355 biological control agent against the Eastern Spruce Budworm (Choristoneura

356 fumiferana). Report \#11 to SERG International. 27pp. Accessed at

357 http://www.serginternational.org/orderreports.html

359 Hicks, B.J., White, S., and Strongman, D. 2011. Microbial control of forest pest 360 caterpillars in Newfoundland and the potential of Beauveria bassiana as a 361 mycoinsecticide. The Osprey 42(4):19-25. 
363 Kirubakaran, S.A., Sathish-Narayanan, S., Revathi, K., Chandrasekaran, R., and Senthil-

364 Nathan S. 2014. Effect of oil-formulated Metarhizium anisopliae and Beauveria

365 bassiana against the rice leafroller Cnaphalocrocis medinalis Guenée (Lepidoptera:

366 Pyralidae). Arch. Phytopathol. Plant Prot. 47:977-992.

368 Krause, C. 1997. The use of dendrochronological material from buildings to get

369 information about past spruce budworm outbreaks. Can. J. For. Res. 27:69-75.

370

371 Li, Z. 2007. Beauveria bassiana for pine caterpillar management in the Peoples Republic

372 of China. In Biological Control. A Global Perspective. Edited by L. Vincent, M.S.

373 Goettel, and G. Lazarovits, CAB International, Wallingford, UK., pp300-310.

375 Morin, H., Laprise, D., and Bergeron, Y. 1993. Chronology of spruce budworm 376 outbreaks near Lake Duparquet, Abitibi region, Quebec. Can. J. For. Res. 23:1497-1506.

378 Moslin, R., Wahid, M.B., Ali, S.R.A., and Kamarudin, N. 2004. The effects of oils on 379 germination of Beauveria bassiana (Balsamo) Vuillemin and its infection against the Oil 380 Palm Bagworm, Metisa plana (Walker). J. Oil Palm Res. 16: 78-87.

382 Prior, C., Jollands, P. and, LePatourel G. 1988. Infectivity of oil and water formulations 383 of Beauveria bassiana (Deuteromycotina:Hyphomycetes) to the cocoa weevil pest 384 Pantorhytes plutus (Coleoptera: Curculionidae). J. Invertebr. Pathol. 52:66-72. 
386 Saik, J.E., Lacey, L.A., and Lacey, C.M. 1990. Safety of microbial insecticides to 387 vertebrates- domestic animals and wildlife. In Safety of Microbial insecticides. Edited by 388 M. Laird, L.A. Lacey, and E.W. Davidson. CRC Press, Boca Raton, pp. 115-132.

390 Semalulu, S.S., MacPherson, J.M., Schiefer, H.B., and Khachatourians G.G. 1992.

391 Pathogenicity of Beauveria bassiana in Mice. J. Vet. Med. B 39:81-90.

393 Ummidi, V.R.S, and Vadlamani P. 2014. Preparation and use of oil formulations of 394 Beauveria bassiana and Metarhizium anisopliae against Spodoptera litura larvae. Afr. J. 395 Microbiol. Res. 8:1638-1644.

397 Vega-Aquino, P., Sanchez-Peña, S., and Blanco C.A. 2010. Activity of oil-formulated 398 conidia of the fungal entomopathogens Nomuraea rileyi and Isaria tenuipes against 399 lepidopterous larvae. J. Invertebr. Pathol. 103:145-149.

401 Vestergaard, S., Cherry, A., Keller, S., and Goettel M. 2003. Safety of hyphomycete 402 fungi as microbial control agents. In, Environmental Impacts of Microbial Insecticides 403 Edited by H.M.T. Hokkanen and A.E. Hajek. Kluwer Academic Publishers, Netherlands, 404 pp. 35-62.

405

406 Wang, C., and Feng M.G. 2014. Advances in fundamental and applied studies in China 407 of fungal biocontrol agents for use against arthropod pests. Biol. Control 68:129-135. 
409 Xu, Q.F. 1988. Some problems about study and application of Beauveria bassiana 410 against agricultural and forest pests in China. In: Study and application of entomogenous

411 fungi in China, Vol. 1. Edited by Y.W. Li, Z.Z. Li, Z.Q. Liang, J.W. Wu, Z.K.Wu and 412 Q.F. Xu. Academic Periodical Press, Beijing, pp 1-9.

413

414 Zimmermann, G. 2007. Review on safety of the entomopathogenic fungi Beauveria 415 bassiana and Beauveria brongniartii. Biocontrol Science and Technology 17:553 - 596. 


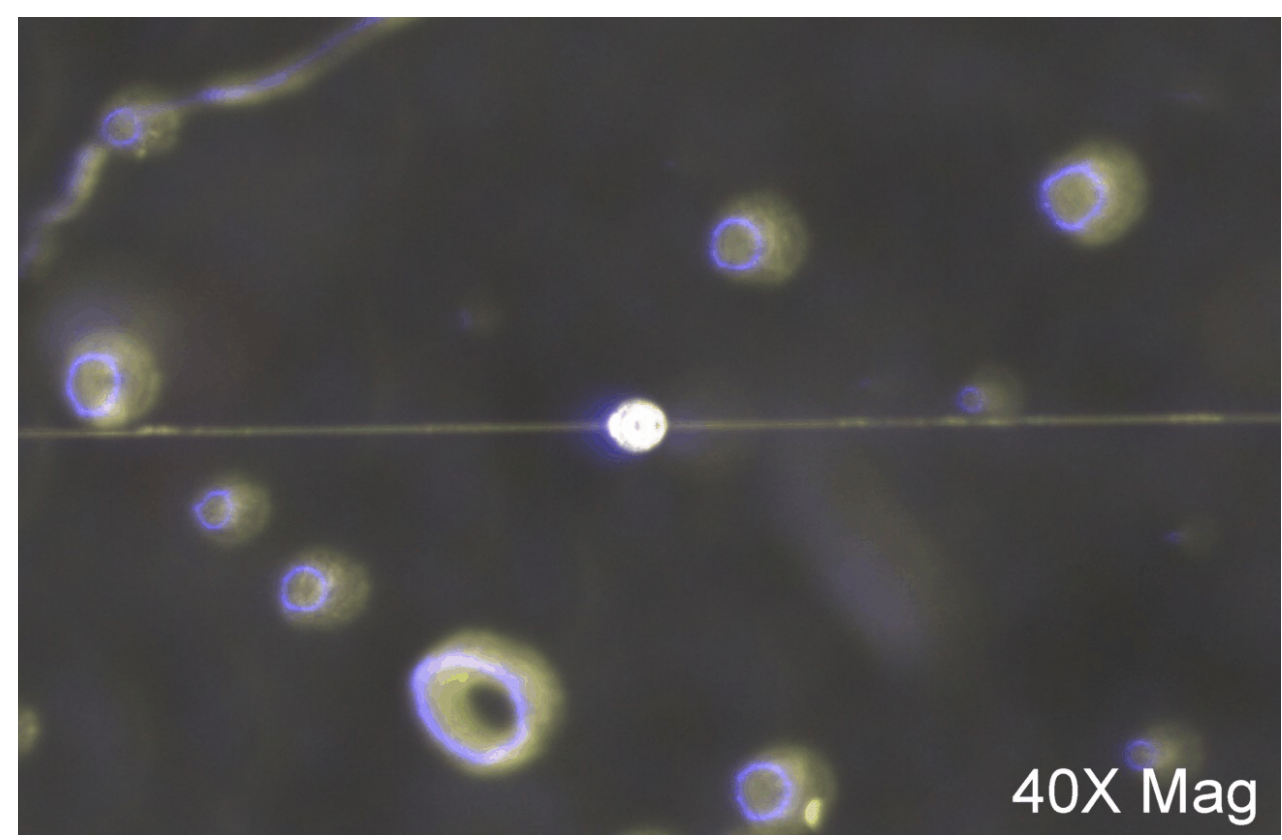

Figure 1. A spray droplet that settled on a thread of spruce budworm silk that was suspended across the well of a depression slide. This allowed for a more accurate measure of the diameter of the droplet sphere. 
Table 1. Topical treatments of $6^{\text {th }}$ instar spruce budworm larvae with mixtures of natural and synthetic oils in kerosene and formulations of spores of the commercial product Botanigard ${ }^{\circledR}$.

\begin{tabular}{lll}
\hline Treatment & Reps. (total insects treated) & $\%$ surviving (SE) \\
\hline Distilled water & $2(20)$ & $90.0(1.0)$ \\
Form- $^{\dagger}$ & $3(30)$ & $13.3(0.67) \mathrm{a}^{*}$ \\
Form- $^{\ddagger}$ & $3(30)$ & $46.7(0.33)$ \\
Botanigard+Form-1 & $3(30)$ & $0(0) \mathrm{a}$ \\
Botanigard+Form-2 & $3(30)$ & $0(0) \mathrm{a}$ \\
\hline
\end{tabular}

${ }^{\dagger}$ Form-1 consisted of 70:30 (mineral oil to kerosene)

Form-2 consisted of 50:50 (general cooking vegetable oil to kerosene)

${ }^{*}$ Values followed by the same letter indicates no significant difference $\mathrm{P}=0.05$

Table 2. Spray tests for test formulations of Beauveria bassiana strains against spruce budworm larvae.

\begin{tabular}{lccc}
\hline Treatment & $\begin{array}{c}\text { \# spores } \\
\text { applied }\end{array}$ & $\begin{array}{c}\text { Reps (total } \\
\text { larvae treated) }\end{array}$ & \% surviving (SE) \\
\hline untreated & - & $4(40)$ & $100(0) \mathrm{a}^{*}$ \\
Distilled water & - & $4(40)$ & $100(0) \mathrm{a}$ \\
Form-2 & - & $4(40)$ & $95(0.29) \mathrm{ab}$ \\
Botanigard $^{(\otimes)}+$ Form2 $-3 \mathrm{secs}$ & 27,648 & $4(40)$ & $82.5(1.03) \mathrm{ab}$ \\
ARSEF 1850+Form2 - 3 secs & 40 & $4(40)$ & $82.5(1.03) \mathrm{ab}$ \\
ARSEF 1850+Form2 - 6 secs & 80 & $4(40)$ & $60(1.47) \mathrm{b}$ \\
\hline
\end{tabular}

${ }^{\dagger}$ Form-2 consisted of 50:50 (general cooking vegetable oil to kerosene)

* Values followed by the same letter indicates no significant difference $\mathrm{P}=0.05$ 
Table 3. Spray trials using a formulation of Botanigard ${ }^{\circledR}$ against spruce budworm larvae where the droplet density and diameter were determined.

\begin{tabular}{lccc}
\hline Treatment & $\begin{array}{l}\text { \# spores } \\
\text { applied }\end{array}$ & $\begin{array}{l}\text { Reps (total } \\
\text { larvae treated) }\end{array}$ & \% surviving (SE) \\
\hline Distilled water & - & $5(50)$ & $96(0.40) \mathrm{a}^{*}$ \\
Form-2 $^{\dagger}$ & - & $5(50)$ & $94(0.25) \mathrm{ab}$ \\
Botanigard $^{\circledR}+$ Form2 -3 secs & $8.58 \times 10^{6}$ & $5(50)$ & $66(1.21) \mathrm{b}$ \\
Botanigard $^{(8)}+$ Form2 -5 secs $^{\circ}$ & $1.43 \times 10^{7}$ & $5(50)$ & $26(0.60)$ \\
\hline
\end{tabular}

${ }^{\dagger}$ Form-2 consisted of 50:50 (general cooking vegetable oil to kerosene)

${ }^{*}$ Values followed by the same letter indicates no significant difference $\mathrm{P}=0.05$

Table 4. Spray trials using a formulation of ARSEF 1850 against spruce budworm larvae where the droplet density and diameter were determined.

\begin{tabular}{lccc}
\hline Treatment & $\begin{array}{l}\text { \# spores } \\
\text { applied }\end{array}$ & $\begin{array}{c}\text { Reps (total } \\
\text { larvae treated) }\end{array}$ & \% surviving (SE) \\
\hline untreated & - & $4(40)$ & $97.5(0.25) \mathrm{a}^{*}$ \\
Form-2 & - & $4(40)$ & $92.5(0.50) \mathrm{a}$ \\
ARSEF 1850 + Form2 -3 secs & 8190 & $4(40)$ & $42.5(1.03)$ \\
ARSEF 1850 + Form2 -6 secs & 16380 & $4(40)$ & $15.0(0.29)$ \\
\hline
\end{tabular}

${ }^{\dagger}$ Form-2 consisted of 50:50 (general cooking vegetable oil to kerosene)

*Values followed by the same letter indicates no significant difference $\mathrm{P}=0.05$ 